\title{
Як вишити фемінізм: схеми і техніки
}

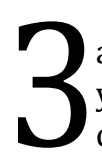

а нинішнього стану речей із його передумовами, мабуть, важко уявити чоловіка, який творитиме щось, переплітаючи нитки. Так само й у ретроспективі. Вишивання, як і всяку пов'язану з текстилем техніку, здавна сприймали як «жіноче» діло, із суто декоративним призначенням, що з часом дедалі відходило на периферію рукодільних практик.

Виставка «TEXTUS. Вишивка, текстиль, фемінізм», що тривала в Центрі візуальної культури від 8 березня до 9 квітня 2017 року, є свого роду апеляцією до патріархального суспільства, де слово й мова є носіями влади й закону. Це третя виставка в серії проектів Оксани Брюховецької: кураторка разом з іншими художницями рефлексує над тим, що́ апріорі вважають «жіночим» у нашому суспільстві. Дві попередні виставки, «Що в мені є від жінки?» та «Материнство», було зосереджено навколо конкретних тем, а цього разу Оксана Брюховецька сформувала проект, фокусуючись на техніці.

Вишивання в загальному уявленні є ремеслом традиційним, а отже, й консервативним. Його асоціюють із чіткими схемами-нормами, чию самобутність закріплено часом. Нині вишивання вважають доволі архаїчною практикою, яка поступилася місцем новим способам вираження сучасного мистецтва. У виставці «TEXTUS» Оксана Брюховецька опонує такому сприйняттю: «Вишивка і текстиль - це рівноправні з іншими медіуми для висловлення ідей у сучасному мистецтві. Вишивка може бути використана як із консервативною метою, так і з метою підірвати консервативність».

Наприклад, швейний кооператив «Швеми» (Анна Тєрєшкіна, Марія Лук'янова, Тоня Мельник і Олеся Панова) деконструює традиціоналістське розуміння одного з найпоширеніших атрибутів із консервативного набору цінностей пострадянських країн. У роботі «Вишиванки» художниці переосмислюють укорінений у соціумі стереотип щодо традиційного одягу. На противагу історичним схемам вишивок, притаманним певним родам або місцевостям, вони створюють власну схему - зображення вагін, що в українському суспільстві зазвичай сприймано як щось принизливе й замовчувано. «Традиційно вишивання - це дисциплінарна 
практика: дівчина повинна була вишивати собі рушники на весілля, що означало їі вписаність у норми, які були патріархальними. "Швеми” вишивають собі сорочки не для шлюбу, а для демонстрації свободи своєї сексуальності, свободи утвердитись у своїй жіночності як у своєму праві самостійно розпоряджатись своїм тілом і своїм життям», - пояснює кураторка.

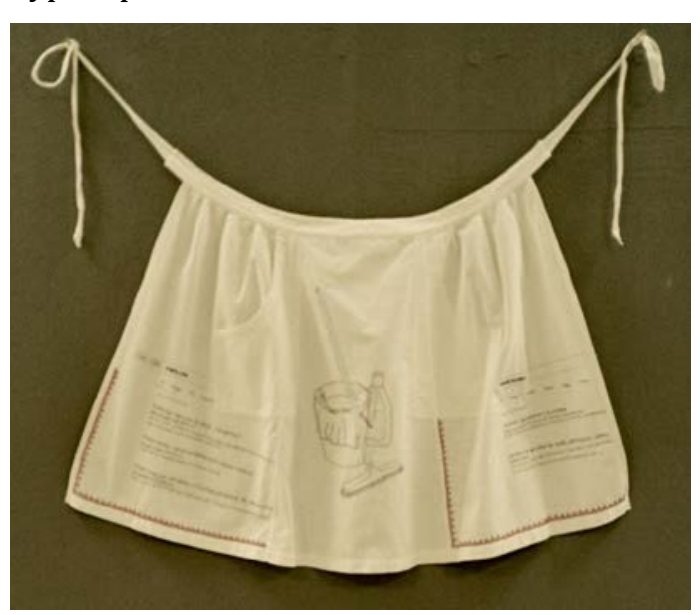

Софія Врємєнная «Ukrajinky úklid / Ukrainki sprzątanie / Українки прибирання».

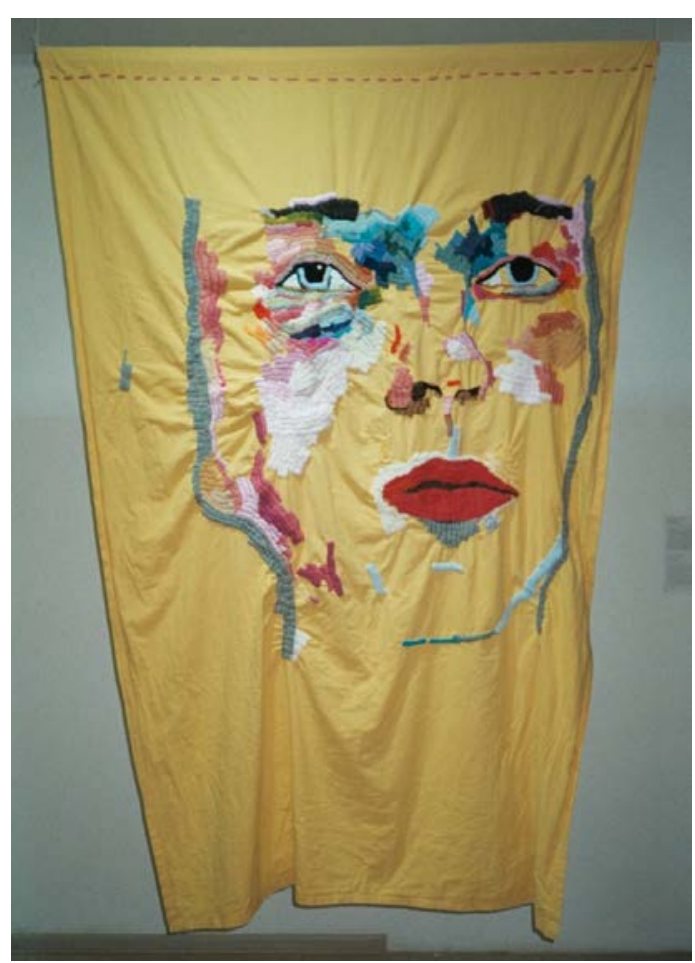

Валентина Петрова "Автопортрет".
Чеська художниця Софія Времєнная теж використовує доволі автентичний атрибут, що реферує до традиціоналізму та загальних уявлень про «суто жіноче». На виставці вона представила роботу «Ukrajinky úklid / Ukrainki sprzątanie / Українки прибирання» фартух із назвами сайтів, які пропонують найману працю українок у Польщі та Чехії. Як зазначає художниця, призначення цього об'єкта легко зчитати: ми бачимо фартух і одразу можемо відтворити картинку жіночої праці, кухні, хатніх обов'язків. Водночас фартух $є$ символом неоціненної праці та подвійного навантаження, що лягають на жіночі плечі в обставинах патріархальної культури.

Тему невидимої праці порушено й в інших експонованих творах феміністичного мистецтва. Зокрема, Валентина Петрова в «Автопортреті» рефлексує над андроцентризмом капіталістичного суспільства. Художниці чуже комерційне мистецтво, яке автоматично відтворює патріархальні канони. Тому Валентина робить свої мистецькі 
проекти антикапіталістичними від початку й до кінця. Вечорами, після основної роботи, художниця вишивала на тканині із секонд-генду нитками, які дісталися їй від родичів і друзів. Поява «Автопортрету» $\epsilon$ початком його зникнення: протягом виставки художниця нитка за ниткою «розшивала» роботу. «Ось це моя боротьба з капіталізмом», - каже Валентина. Зникомий автопортрет не просто відображає зовнішність авторки, а передусім є, за словами кураторки, «маніфестацією свідомого протесту проти підпорядкування капіталістичному арт-ринку».

«Швеми» рефлексують на тему невидимої та неоціненої праці в роботі «12-годинний робочий день». Художниці представили відеозапис свого перформансу, під час якого відтворювали умови, якомога наближеніші до умов праці жінок на швейних фабриках третього світу: дванадцятигодинний робочий день із п'ятнадцятихвилинною перервою на перекус, тісне приміщення, монотонна праця, три виходи в туалет і розмови лише по ділу. Наприкінці учасниці продавали свої вироби з написами «Зроблено в рабстві» по 44 рублі - приблизно стільки отримує за кожну річ колектив робітниць на швейній фабриці. Так художниці висловили солідарність із виснаженими життям і репродуктивною працею швачками.

Оксана Брюховецька в роботі «Батоги» привертає увагу до соціального насильства, часто невидимого, якого жінки зазнають ще змалку. Період первинної соціалізації стає нескінченним ланцюжком практик із принципом «наглядати й карати». Сплетені в коси яскраві дівчачі колготки - метафора так званих «дисциплінарних батогів», що нависають над жінками з дитинства, виховуючи відповідні соціальні ідеали.

Цю риторику продовжує Аліна Клейтман у роботі «Перші п'ять років нашого подружжя твій батько взагалі не знав, що у мене росте волосся». Авторка порушує тему соціального насильства, що загрожує жінкам і впливає на їхній внутрішній стан і зовнішній вигляд. Досягаючи певного віку, жінка починає носити капронові колготи або панчохи. Ці елементи гардероба стають інструментами об'єктивації жіночого тіла у фалічній патріархальній системі, яка, своєю чергою, регулює жі-

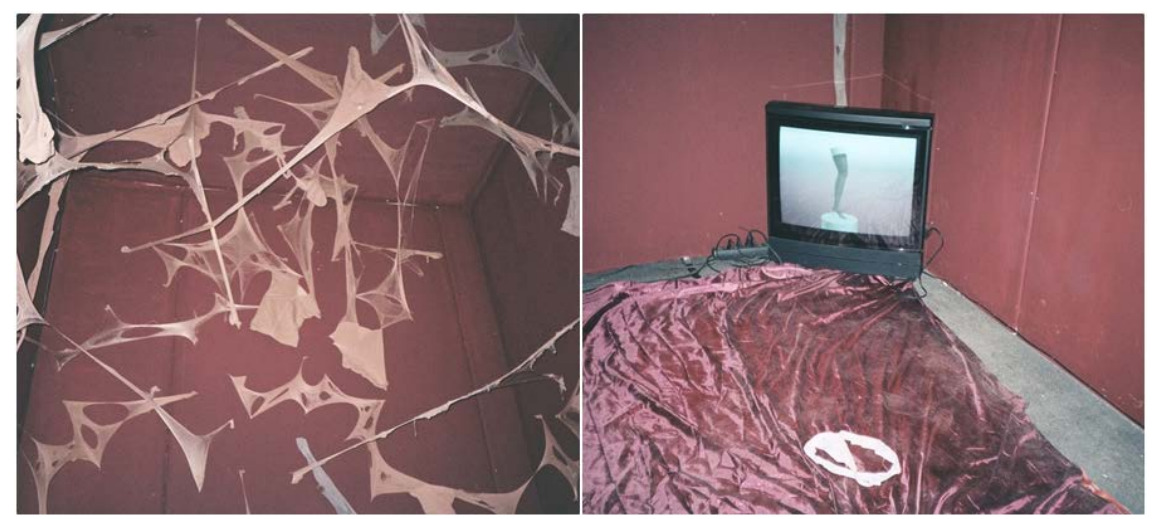

Аліна Клейтман «Перші п'ять років нашого подружжя твій батько взагалі не знав що у мене росте волосся». 
:- $\quad$ ночі практики щодо найітимніших частин тіла, що мусять відповідати канонічним нормам.

Виставка «TEXTUS», як зазначає Оксана Брюховецька, є не пропагандою гендерної нерівності з протилежним знаком, а полем для феміністичних рефлексій сучасних українських мисткинь щодо усталеного патріархального образу жінки. Вишивка й текстиль стали інструментарієм художниць для висловлення критичних поглядів на звичне суспільно «прийнятне», яке, втім, може бути болісним, разючим, несправедливим. 